\title{
KAJIAN BEBAN PENCEMARAN LIMBAH CAIR DENGAN PARAMETER BOD DAN DO DARI AREA PERMUKIMAN DI SUNGAI CITEPUS
}

\author{
Hary Pradiko*, Yonik Meilawati Yustiani, Santika \\ Program Studi Teknik Lingkungan, Universitas Pasundan
}

\begin{abstract}
Abstrak
Sungai Citepus merupakan sungai yang mengalir melalui daerah Barat kota Bandung dengan berbagai kegiatan masyarakatnya, antara lain permukiman padat/ kegiatan penduduk sehari-hari seperti MCK, home industri atau industri kecil, sehingga sungai Citepus juga merupakan tempat yang potensi untuk pembuangan air limbah dari kegiatan tersebut. Dalam penelitian ini menggunakan metode analisis kualitas air sungai, berdasarkan kualitas indikator pencemaran di Sungai Citepus yang telah dilakukan pada musim hujan. Pengambilan sampel air dilakukan secara sesaat/grab, pengambilan sampel dilakukan di 5 titik pengamatan dimulai di daerah hulu (j1.Dr.Setiabudhi) sampai hilir (Jl.Caringin).Tingkat pencemaran air sungai ditentukan berdasarkan parameter kualitas air BOD dan DO. Persamaan yang digunakan adalah Teori Streeter - Phelps. Dari hasil perhitungan diperoleh bagian hulu sungai kadar BOD-nya antara 6,8 - 7,2 mg/l dan kadar DO 8,4 mg/l. dan dibagian hilir sungai kadar BOD-nya antara 7,0 - 7,5 mg/l dan kadar DO 0,5 - 0,9 mg/l. Berdasarkan hasil diatas maka kondisi sungai dibadian hulu kadar BOD di daerah ini telah melebihi ambang batas (tercemar), tetapi nilai DO sesuai dengan ambang batas, begitu juga dengan bagian hilir sungai nilai BOD telah melewati ambang batas (tercemar) dan kadar DO dibawah ambang batas, menurut SK Gubernur Jawa Barat N0.39 Tahun 2001 yaitu nilai BOD sebesar $6 \mathrm{mg} / \mathrm{l}$ dan DO sebesar $>3 \mathrm{mg} / \mathrm{l}$.
\end{abstract}

Kata kunci: Kualitas Air Sungai, BOD, DO, Streeter-Phelps

\section{Pendahuluan}

Pada saat ini kerusakan sumber air tidak dapat terelakkan. Salah satu penyebab kerusakan tersebut berkaitan erat dengan pesatnya laju pertumbuhan penduduk dan makin meningkatnya kegiatan perekonomian masyarakat, yang sebagian besar penduduk tidak perduli dan kurangnya pengetahuan akan pentingnya menjaga kelestarian sumber air.

Karena salah satui fungsinya sebagai sumber air bersih maka kualitas airnya harus diperhatikan. Pencemaran yang ada di sungai diakibatkan berbagai aktivitas yang langsung dibuang ke

\footnotetext{
${ }^{*}$ Penulis Korespondensi:

E-mail: harypradiko@unpas.ac.id

Diterima pertama kali: 7 Maret 2018

Direvisi : 10 Juni 2018

Disetujui untuk publikasi: 29 Juli 2018
}

badan air, salah satunya berasal dari buangan domestik (Yustiani, Mulyatna, \& Pranata, 2013).

Pembuangan air limbah domestik harus melalui tangki pengolahan untuk menghindari kontaminasi pencemaran air tanah atau air baku permukaan, dengan tujuan utama untuk perlindungan kesehatan masyarakat di kawasan permukiman. Disamping itu harus tersedia fasilitas pendukung seperti MCK umum yang sesuai dengan kebutuhan.

Tingginya beban pencemaran organik pada sungai berpengaruh terhadap kualitas air sungai, kondisi air yang kotor menyebabkan menurunnya kadar oksigen terlarut dalam air yang bila kondisi tersebut terus berlangsung mengakibatkan ikan dan kehidupan akuatik lainnya tidak mendapatkan oksigen yang cukup untuk mempertahankan hidupnya . 
Selain itu, pencemaran organik yang tinggi pada sungai dapat mengakibatkan gangguan estetika lingkungan seperti timbulnya bau tidak sedap dan perubahan warna air. Dengan tingkat kepadatan yang tinggi dan tingkat ekonomi yang rendah, menyebabkan sebagian penduduk di sekitar Sungai Citepus membuang tinjanya dan hasil kegiatan lainnya yang menghasilkan limbah ke badan sungai Citepus tanpa melalui proses pengolahan terlebih dahulu. Potensi tinggi terjadinya pencemaran ini perlu dikaji agar tindak pemulihan dan pencegahan dapat dilakukan. Berdasarkan hal tersebut, oleh sebab itu tujuan dari kajian ini adalah menghitung beban pencemar domestik dari area permukiman pada Sungai Citepus.

\section{Metodologi}

\section{Lokasi Penelitian}

Lokasi penelitian ini adalah Subdas Citepus. Gambar 1 memperlihatkan subdas tersebut.

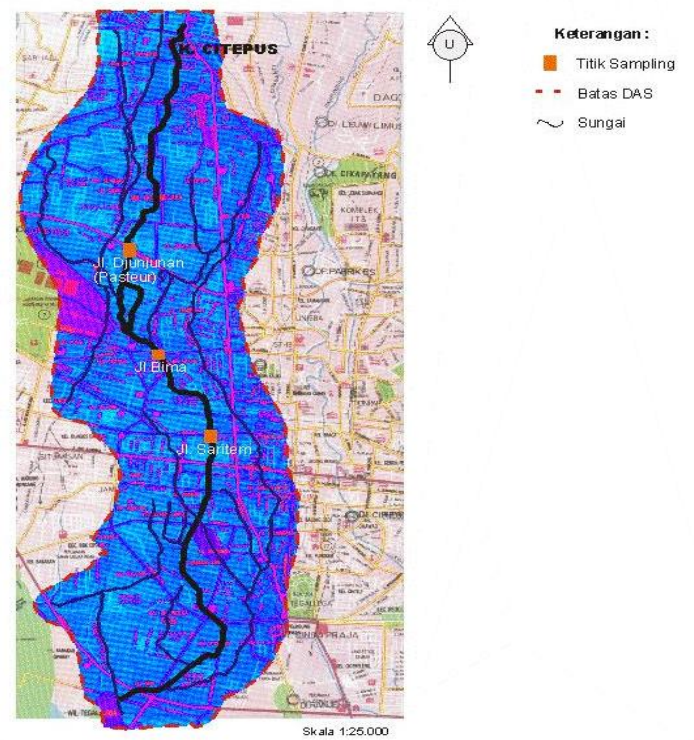

Gambar 1. Peta Subdas Citepus.

Pengambilan sampel air dilakukan dengan lima titik sampling yaitu di lima tempat :

- Titik 1 = bagian hulu sungai (jl. Dr. Setiabudhi)

- $\quad$ titk 2 = jl. Pasteur

- $\quad$ titik $3=$ jl. Padjajaran
- $\quad$ titik $4=$ jl. Kebonjati

- $\quad$ titik 5 = bagian hilir sungai (jl. Caringin)

\section{Penentuan Titik Pengambilan Contoh Air}

Untuk menentukan titik pengambilan contoh air perlu dilakukan survey pendahuluan yang berguna untuk mengetahui kondisi sebenarnya dari wilayah studi yang meliputi keadaan topografi, geologi, kondisi sosial masyarakat, industri yang berada di sekitar lokasi, dan lain - lain. Lokasi pengambilan contoh air juga didasarkan pada lokasi yang belum terjadi / masih sedikit pencemaran, dan di hilir sebagai tempat yang banyak mengalami pencemaran.

\section{Waktu dan Metode Sampling}

Untuk keperluan penelitian ini dilakukan pengambilan sampel di lima titik, dimana parameter yang diukur adalah DO, temperatur, BOD, Debit. Untuk keperluan perhitungan model pencemaran organik pada sungai diperlukan beberapa parameter penting terutama koefisien deoksigenasi $\left(\mathrm{K}_{\mathrm{d}}\right)$, Koefisien reaerasi $\left(\mathrm{K}_{\mathrm{a}}\right)$ dan debit sesaat serta dimensi dari sungai. Adapun metode pengambilan contoh air dilakukan secara grab sampling (sesaat).

\section{Analisa Air}

Parameter yang diukur adalah sebagai berikut :

1. Pengukuran DO menggunakan alat DO meter

2. Pengukuran temperatur air menggunakan alat termometer

3. Pengukuran kecepatan aliran menggunakan metoda floating method

4. Perhitungan Debit sungai

5. Pengukuran konsentrasi BOD, Dalam pengukuran konsentrasi BOD dan DO dilakukan di Laboratorium.

\section{Estimasi Beban Pencemaran Organik}

Harga parameter DO dan BOD teoritis, dihitung menggunakan model matematis dengan beban 
pencemaran organik secara teoritis pula. Beban pencemaran organik secara teoritis dihitung berdasarkan jumlah penduduk (Pangestu, Riani, \& Effendi, 2017). Di daerah aliran sungai diperkirakan membuang limbah domestik ke sungai, selain itu perlu diketahui beban pencemaran yang diakibatkan oleh aktivitas komersial dan institusi seperti pasar, supermarket, dan kantor.

Untuk memperoleh beban pencemaran teoritis yang paling mendekati keadaan sesungguhnya di lapangan, perlu dilakukan perhitungan dengan menggunakan berbagai kemungkinan beban pencemaran. Sehingga dapat diperkirakan jumlah dan kualitas air buangan yang masuk ke setiap titik pengamatan di sepanjang aliran sungai.

Beban pencemaran di setiap titik pengamatan hasil perhitungan teoritis dengan berbagai asumsi beban pencemaran tersebut, dibandingkan dengan beban pencemaran hasil observasi, yang kemudian dipilih perhitungan yang paling mendekati dengan hasil observasi.

\section{Penerapan Model Matematis}

Studi perbandingan dilakukan terutama untuk mengetahui perbedaan antara harga BOD dan DO pada titik observasi dengan hasil perhitungan teoritis menggunakan rumus Model BOD dan DO menurut Thomann.

Persamaan untuk BOD adalah :

$\mathrm{L}=\mathrm{L}_{\mathrm{o}} \mathrm{e} \frac{-K_{r}}{U} X$

Sedangkan Persamaan untuk Defisit Oksigen terlarut adalah :

$\mathrm{D}=\mathrm{D}_{\mathrm{o}} \cdot \mathrm{e} \frac{-K a}{U} X+\frac{K d \cdot L o}{K a-K r}\left[e^{-\frac{k r}{u} x}-e^{-\frac{k a}{u} x}\right]$

Dimana :

$\mathrm{D}=$ Defisit oksigen terlarut pada saat $\mathrm{t},(\mathrm{mg} / \mathrm{l})$

$\mathrm{X}=$ Jarak titik pengamatan $(\mathrm{km})$
$\mathrm{L}_{\mathrm{o}}=$ konsentrasi BOD limpasan $(\mathrm{t}=0),(\mathrm{mg} / \mathrm{l})$

$\mathrm{D}_{\mathrm{o}}=\mathrm{DO}$ defisit awal pada titik pembuangan $(\mathrm{t}$ $=0),(\mathrm{mg} / \mathrm{l})$

$\mathrm{K}_{\mathrm{d}}=$ koefisien deoksigenasi $(1 / \mathrm{hr})$

$\mathrm{K}_{\mathrm{r}}=$ koefisien penyisihan BOD keseluruhan $\left(\right.$ hari $^{-1}$ )

$\mathrm{K}_{\mathrm{a}}=$ koefisien reaerasi $(1 / \mathrm{hr})$

$\mathrm{U}=$ Kecepatan rata - rata $(\mathrm{m} / \mathrm{det})$

\section{Rumus Untuk Mencari Koefisien Deoksigenasi $(K d)$}

Koefisien deoksigenasi yang digunakan untuk perhitungan model pencemaran organik air digunakan formula yaitu rumus menurut O'Conner and Dobbins untuk aliran normal adalah sebagai berikut :

$\mathrm{K}_{\mathrm{d}}=0,3\left[\frac{\text { Hrata }- \text { rata }}{8}\right]^{-0,434}$

Dimana :

$\mathrm{K}_{\mathrm{d}}=$ Koefisien deoksigenasi $\left(\right.$ hari $^{-1}$ )

$\mathrm{H}=$ Kedalaman $(\mathrm{m})$

Rumus Untuk Mencari Nilai Koefisien Reaerasi $\left(K_{a}\right)$

Beberapa metode yang dapat digunakan untuk mendapatkan harga $\mathrm{K}_{2}$ adalah menggunakan model yaitu rumus menurut O'Conner and Dobbins untuk aliran normal adalah sebagai berikut :

$\mathrm{K}_{\mathrm{a}}=3,93 \frac{\text { Urata }- \text { rata }^{0,5}}{\text { Hrata }- \text { rata }^{1,5}}$

Dimana :

$\mathrm{K}_{\mathrm{a}}=$ Koefisien reaerasi $\left(\right.$ hari $^{-1)}$

$\mathrm{U}=$ kecepatan rata-rata $(\mathrm{m} / \mathrm{dt})$

$\mathrm{H}=$ kedalaman rata-rata $(\mathrm{m})$ 


\section{Perhitungan Nilai Laju Total Penyisihan}

$\left(K_{r}\right)$

Untuk mencari nilai total removal $\left(\mathrm{K}_{\mathrm{r}}\right)$ di perlukan nilai kecepatan pengendapan $\left(\mathrm{V}_{\mathrm{s}}\right)$ dan laju pengendapan $\left(\mathrm{K}_{\mathrm{s}}\right.$, dimana rumus yang digunakan adalah :

$\mathbf{V}_{\mathrm{s}=} \frac{H}{t}$

Dimana :

$\mathrm{V}_{\mathrm{s}}=$ kecepatan mengendap segmen $(\mathrm{m} / \mathrm{det})$

$\mathrm{H}=$ Kedalaman sample rata-rata $(\mathrm{m})$

$\mathrm{t}=$ waktu pengendapan rata-rata (det)

Dengan rumus diatas maka nilai $\mathrm{K}_{\mathrm{s}}$ pertitik dapat diketahui dengan menggunakan rumus sebagai berikut:

$\mathrm{K}_{\mathrm{s}}=\frac{V_{s}}{H}$

Dimana :

$\mathrm{K}_{\mathrm{s}}=$ Laju Pengendapan $\left(\right.$ hari $^{-1}$ )

$\mathrm{V}_{\mathrm{s}}=$ kecepatan mengendap (m/hari)

$\mathrm{H}=$ kedalaman sungai $(\mathrm{m})$

Nilai $K_{d}$ dan $K_{\mathrm{s}}$ sudah diketahui maka didapat nilai Total Penyisihan $\left(\mathrm{K}_{\mathrm{r}}\right)$ pada sungai Citepus. Rumus untuk mencari $\mathrm{K}_{\mathrm{r}}$, adalah sebagai berikut:

$\mathrm{K}_{\mathrm{r}}=\mathrm{K}_{\mathrm{d}}+\mathrm{K}_{\mathrm{s}}$

Dimana :

$\mathrm{K}_{\mathrm{r}}=$ Total penyisihan $\left(\right.$ hari $\left.^{-1}\right)$

$\mathrm{K}_{\mathrm{d}}=$ Koefisien Deoksigenasi $\left(\right.$ hari $^{-1}$ )

$\mathrm{K}_{\mathrm{s}}=$ Laju Pengendapan $\left(\right.$ hari $\left.^{-1}\right)$

\section{Hasil dan Pembahasan}

\section{Pembagian Segmen}

Sungai Citepus dengan panjang saluran dari hulu hingga hilir sepanjang 14,5 km dibagi menjadi beberapa segmen berdasarkan pada beban pencemaran yang masuk ke badan sungai
Citepus yang disebabkan oleh limbah domestik ataupun limbah industri.

Pengambilan sampel di dasarkan pada lima kelurahan yang dianggap dapat mewakili perhitungan beban pencemar limbah cair. Adapun ke lima titik tersebut dapat di lihat pada Tabel 1.

Tabel 4.1. Lokasi pengambilan sample di Sungai Citepus

\begin{tabular}{ccc}
\hline Titik & $\begin{array}{c}\text { Jarak Titik } \\
\text { Pengambilan } \\
\text { sample (Km) }\end{array}$ & $\begin{array}{c}\text { Lokasi } \\
\text { pengambilan } \\
\text { Sampel }\end{array}$ \\
\hline 1 & 0 & Jl. Dr. Setiabudi \\
\hline 2 & 3,75 & Jl. Pasteur \\
\hline 3 & 5,37 & Jl. Padjajaran \\
\hline 4 & 7,37 & Jl. Kebonjati \\
\hline 5 & 14,5 & Jl. Caringin \\
\hline
\end{tabular}

\section{Perhitungan koefisien Reaerasi $\left(K_{a}\right)$}

Koefisien Reaerasi yang digunakan untuk perhitungan model pencemaran organik air digunakan formula O'Connor - Dobbins untuk aliran normal pada Sungai Citepus dapat dilihat pada Tabel 2.

Tabel 2. Hasil Perhitungan Koefisien Reaerasi

$\left(\mathrm{K}_{\mathrm{a}}\right)$

\begin{tabular}{cccc}
\hline $\begin{array}{c}\text { Jarak Titik } \\
\text { Pengamatan } \\
(\mathbf{k m})\end{array}$ & $\begin{array}{c}\text { Kedalaman } \\
(\mathbf{m}) \\
\text { rata-rata }\end{array}$ & $\begin{array}{c}\text { Kecepatan } \\
(\mathbf{m} / \mathbf{d t})\end{array}$ & $\begin{array}{c}\text { Ka } \\
\text { rata-rata }\end{array}$ \\
$0-3,75$ & 0,5 & 0,17 & \\
$3,75-5,37$ & 0,7 & 0,24 & 3,574 \\
$5,37-7,37$ & 0,78 & 0,27 & 2,96 \\
$7,37-14,5$ & 0,8 & 0,17 & 2,262 \\
\hline
\end{tabular}

Perhitungan koefisien Deoksigenasi $(K d)$

Untuk mencari koefisien Deoksigenasi digunakan rumus menurut Hydroscince, 1991 adalah sebagai berikut :

$\mathrm{K}_{\mathrm{d}}=0,3\left[\frac{H}{8}\right]^{-0,434}$, jika $0 \leq \mathrm{H} \leq 2,4 \mathrm{~m}$

$\mathrm{K}_{\mathrm{d}}=0,3$; jika $\mathrm{H} \geq 2,4 \mathrm{~m}$

Adapun perhitungan koefisien Deoksigenasi $\left(\mathrm{K}_{\mathrm{d}}\right)$ dapat di lihat pada Tabel 3. 
Tabel 3. Hasil Perhitungan Koefisien Deokigenasi $\left(\mathrm{K}_{\mathrm{d}}\right)$

\begin{tabular}{|c|c|c|c|c|}
\hline \multirow{2}{*}{$\begin{array}{c}\text { Jarak Titik } \\
\text { Pengamatan } \\
(\mathbf{k m})\end{array}$} & \multicolumn{3}{|c|}{ Kedalaman (H) } & \multirow{2}{*}{$\begin{array}{c}\text { Kd } \\
\left(\begin{array}{c}\text { Hari } \\
1\end{array}\right)\end{array}$} \\
\hline & $\begin{array}{l}\text { titik } \\
\text { awal }\end{array}$ & $\begin{array}{c}\text { titik } \\
\text { akhir }\end{array}$ & $\begin{array}{c}\text { rata- } \\
\text { rata }\end{array}$ & \\
\hline $0-3,75$ & 0,4 & 0,6 & 0,5 & 0,999 \\
\hline $3,75-5,37$ & 0,6 & 0,8 & 0,7 & 0,864 \\
\hline $5,37-7,37$ & 0,8 & 0,75 & 0,78 & 0,824 \\
\hline $7,37-14,5$ & 0,75 & 0,85 & 0,8 & 0,815 \\
\hline
\end{tabular}

\section{Perhitungan Nilai Laju Total Penyisihan}

$\left(K_{r}\right)$

Untuk mencari nilai total removal $\left(\mathrm{K}_{\mathrm{r}}\right)$ di perlukan nilai kecepatan pengendapan $\left(\mathrm{V}_{\mathrm{s}}\right)$ dan laju pengendapan (Ks). Hasil perhitungan dapat dilihat pada Tabel 4, Tabel 5, dan Tabel 6.

Tabel 4. Hasil Perhitungan Kecepatan Pengendapan (Vs)

\begin{tabular}{ccc}
\hline $\begin{array}{c}\text { Kedalaman Sampel } \\
\text { dalam Inhoff }(\mathbf{m})\end{array}$ & $\begin{array}{c}\text { Waktu } \\
\text { (hari) }\end{array}$ & $\begin{array}{c}\text { Vs rata2 } \\
(\mathbf{m} / \mathbf{h r})\end{array}$ \\
\hline 0,325 & 0,077 & 4,221 \\
\hline 0,325 & 0,074 & 4,392 \\
\hline 0,325 & 0,068 & 4,779 \\
\hline 0,325 & 0,051 & 6,373 \\
\hline
\end{tabular}

Tabel 5. Tabel Perhitungan Nilai Ks

\begin{tabular}{|c|c|c|c|c|}
\hline \multicolumn{3}{|c|}{ Kedalaman (H) } & \multirow[b]{2}{*}{$\begin{array}{c}\text { Vs } \\
\text { (m/hari) }\end{array}$} & \multirow[b]{2}{*}{$\begin{array}{c}\text { Ks } \\
\left(\text { hari }^{-1}\right)\end{array}$} \\
\hline $\begin{array}{l}\text { titik } \\
\text { awal }\end{array}$ & $\begin{array}{c}\text { titik } \\
\text { akhir }\end{array}$ & $\begin{array}{l}\text { rata- } \\
\text { rata }\end{array}$ & & \\
\hline 0,4 & 0,6 & 0,5 & 4,221 & 8,442 \\
\hline 0,6 & 0,8 & 0,7 & 4,392 & 6,274 \\
\hline 0,8 & 0,75 & 0,78 & 4,779 & 6,127 \\
\hline 0,75 & 0,85 & 0,8 & 6,373 & 7,966 \\
\hline
\end{tabular}

Tabel 6. Tabel Perhitungan Nilai $\mathrm{K}_{\mathrm{r}}$ Jarak Titik

Pengamatan Kd Ks $\quad$ Kr \begin{tabular}{llll}
$(\mathbf{k m})$ & $\left(\right.$ hari $\left.^{-1}\right)$ & $\left(\right.$ hari $\left.^{-1}\right)$ & $\left(\right.$ hari $\left.^{-1}\right)$ \\
\hline
\end{tabular}

\begin{tabular}{cccc}
$\mathbf{( k m})$ & $\left(\right.$ hari $\left.^{-1}\right)$ & (hari $\left.^{-1}\right)$ & (hari $\left.^{-1}\right)$ \\
\hline $0-3,75$ & 0,999 & 8,442 & 9,441 \\
\hline $3,75-5,37$ & 0,864 & 6,274 & 7,138 \\
\hline $5,37-7,37$ & 0,824 & 6,127 & 6,951 \\
\hline $7,37-14,5$ & 0,815 & 7,966 & 8,781 \\
\hline
\end{tabular}

\section{Perhitungan Konsentrasi BOD}

Nilai konsentrasi BOD Sungai Citepus dari hasil perhitungan dengan menggunakan Model Thomann diperoleh dengan memasukan data berupa debit, koefisien Reaerasi (Ka), koefisien Deoksigenasi (Kd), dan Total Removal (Kr).

Hasil perhituhan dapat dilihat pada Tabel 7.

Tabel 7. Hasil Perhitungan Nilai Konsentrasi BOD

\begin{tabular}{|c|c|c|c|c|c|c|c|c|c|c|c|}
\hline $\begin{array}{c}\text { Segmen } \\
(\mathbf{k m})\end{array}$ & $\begin{array}{c}\text { Sub } \\
\text { Segmen } \\
(\mathbf{k m})\end{array}$ & $\begin{array}{l}\text { Titik } \\
\text { (km) }\end{array}$ & $\begin{array}{c}\mathbf{K r} \\
\left(\text { hari }^{-1}\right)\end{array}$ & $\begin{array}{c}\mathrm{U} \\
\text { (m/det) }\end{array}$ & $\begin{array}{c}\mathbf{X} \\
(\mathbf{m})\end{array}$ & $\begin{array}{c}\text { Qo } \\
\text { (m3/det) }\end{array}$ & $\begin{array}{c}\text { Qb } \\
\text { (m3/det) }\end{array}$ & $\begin{array}{c}\mathrm{Qt} \\
\text { (m3/det) }\end{array}$ & $\begin{array}{c}\text { Lo } \\
(\mathrm{mg} / \mathrm{l})\end{array}$ & $\begin{array}{c}\mathrm{Lb} \\
(\mathrm{mg} / \mathrm{l})\end{array}$ & $\begin{array}{c}\mathbf{L}_{\mathbf{x}} \\
(\mathbf{m g} / \mathbf{l})\end{array}$ \\
\hline 1 & 2 & 3 & 4 & 5 & 6 & 7 & 8 & 9 & 10 & 11 & 12 \\
\hline \multirow{3}{*}{$0-3,75$} & $0-2$ & & $1,093 \times 10^{-4}$ & 0,17 & 2000 & & & & 6,8 & & 1,88 \\
\hline & & 2 & & & & 0,57 & 0,18 & 0,75 & & 86,34 & \\
\hline & $2-3,75$ & & $1,093 \times 10^{-4}$ & 0,17 & 1750 & & & & 22,15 & & 7,2 \\
\hline \multirow{3}{*}{$3,75-5,37$} & $3,75-4$ & & $8,262 \times 10^{-5}$ & 0,24 & 250 & & & & 7,2 & & 6,6 \\
\hline & & 4 & & & & 0,75 & 1,23 & 1,98 & & 15,5 & \\
\hline & $4-5,37$ & & $8,262 \times 10^{-5}$ & 0,24 & 1370 & & & & 12,12 & & 7,56 \\
\hline \multirow{3}{*}{$5,37-7,37$} & $5,37-6$ & & $8,045 \times 10^{-5}$ & 0,27 & 630 & & & & 7,56 & & 6,26 \\
\hline & & 6 & & & & 1,98 & $\mathbf{0 , 0 3}$ & 1,40 & & 205 & \\
\hline & $6-7,37$ & & $8,045 \times 10^{-5}$ & 0,27 & 1370 & & & & 10,53 & & 7 \\
\hline \multirow{3}{*}{$7,37-14,5$} & $7,37-10$ & & $1,016 \times 10^{-4}$ & 0,17 & 2630 & & & & 7 & & 1,46 \\
\hline & & 10 & & & & 1,4 & $\mathbf{0 , 0 7}$ & 1,04 & & 1466 & \\
\hline & $10-14,5$ & & $1,016 \times 10^{-4}$ & 0,17 & 4500 & & & & 100 & & 7,5 \\
\hline
\end{tabular}

Dilihat dari hasil perhitungan di atas terjadi naik turun nilai BOD antara segmen yang satu dengan yang lainnya, terutama kenaikan terjadi di titik $10 \mathrm{~km}$, hal tersebut diakibatkan banyaknya jumlah penduduk yang tinggal di segmen tersebut, sehingga pembuangan air 
limbah menjadi lebih banyak, sehingga nilai BOD di titik tersebut mengalami kenaikan yang besar.

Perhitungan Konsentrasi Defisit Oksigen $\left(D_{x}\right)$

Nilai konsentrasi DO Sungai Citepus dari hasil perhitungan dengan menggunakan Model
Thomann diperoleh dengan memasukan data berupa debit, koefisien Reaerasi (Ka), koefisien Deoksigenasi $(\mathrm{Kd})$, dan Total penyisihan $(\mathrm{Kr})$, sebelum menghitung konsentrasi Defisit Oksigen $\left(\mathrm{D}_{\mathrm{x}}\right)$ dilakukan perhitungan $\left(\mathrm{D}_{\mathrm{o}}\right)$ terlebih dahulu. Hasil perhitungan defisit oksigen dapat dilihat pada Tabel 8.

Tabel 8. Hasil Perhitungan Nilai Konsentrasi Defisit Oksigen $\left(D_{X}\right)$

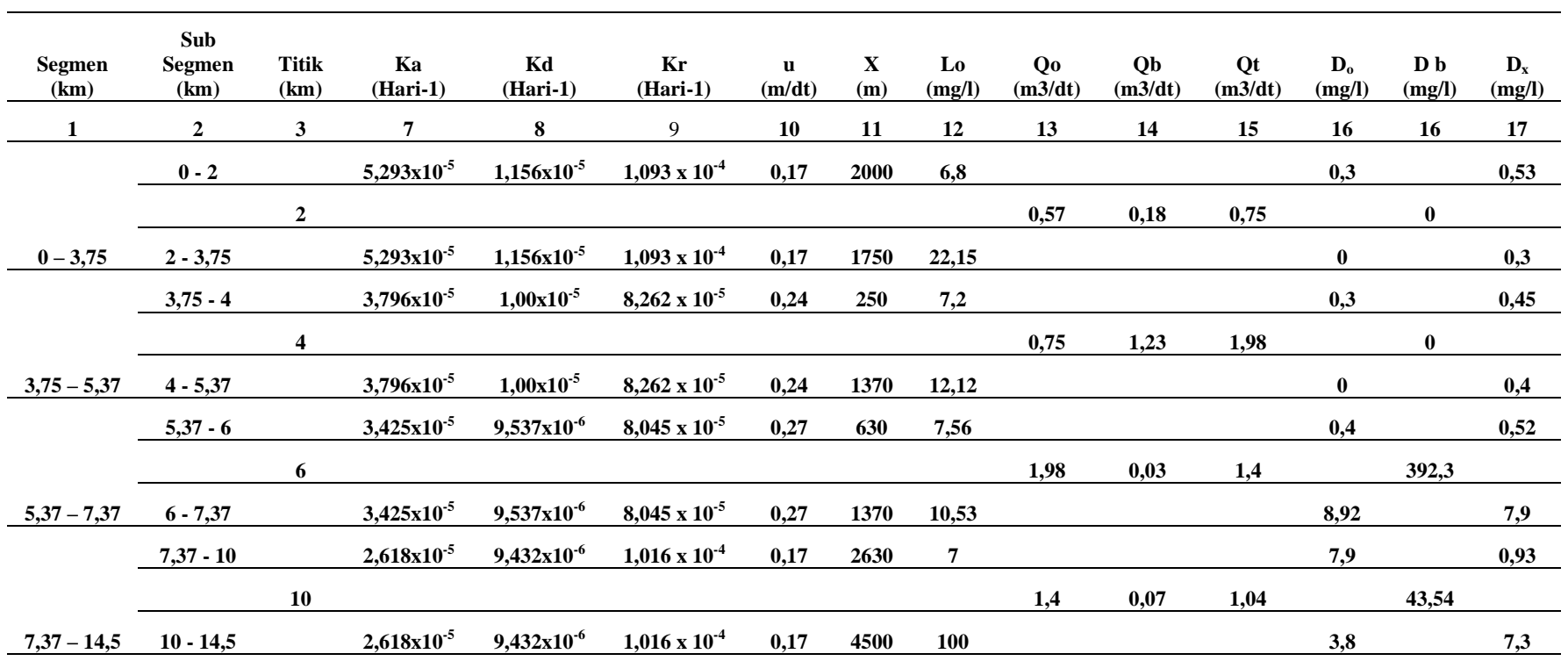

\section{Pembahasan}

Segmen $0 \mathrm{~km}-3,75 \mathrm{kms}$

- DO di bagian hulu $0,53 \mathrm{mg} / \mathrm{l}$ dan dibagian hilir 0,3 mg/l. Dari hasil perhitungan DO kita bisa melihat adanya penurunan nilai oksigen terlarut, hal ini terjadi karena banyaknya konsentrasi pencemar yang masuk terutama dari buangan domestik, yang mengakibatkan kandungan oksigen di daerah ini menjadi turun.

- BOD dibagian hulu 1,88 mg/l dan dibagian hilir 7,2 mg/l. dari hasil perhitungan BOD kita bisa melihat adanya kenaikan nilai BOD yang sangat besar hal ini disebabkan karena adanya masukan beban pencemar di titik 2 $\mathrm{km}$ yaitu sebesar $86,34 \mathrm{mg} / \mathrm{l}$, selain itu juga dipengaruhi jumlah penduduk antara hulu sungai dengan hilir sungai.

- Beban buangan di segmen ini sebesar 86,34 $\mathrm{mg} / \mathrm{l}$ maka dapat diketahui beban buangan tiap harinya yaitu sebesar 1,35 ton/hari.

Segmen $3,75 \mathrm{~km}-5,37 \mathrm{~km}$

- DO di bagian hulu $0,45 \mathrm{mg} / \mathrm{l}$ dan di bagian hilir $0,4 \mathrm{mg} / \mathrm{l}$. Dari hasil perhitungan DO kita bisa melihat adanya penurunan nilai oksigen terlarut, hal ini terjadi karena banyaknya konsentrasi pencemar yang masuk terutama dari buangan domestik, yang mengakibatkan kandungan oksigen di daerah ini menjadi turun.

- BOD dibagian hulu $6,6 \mathrm{mg} / \mathrm{l}$ dan dibagian hilir 7,56 mg/l. dari hasil perhitungan BOD 
kita bisa melihat adanya kenaikan nilai BOD, hal ini disebabkan karena adanya masukan beban pencemar di titik $4 \mathrm{~km}$ yaitu sebesar 15,5 mg/l, selain itu kemungkinan lonjakan konsentrasi di akhir segmen terjadi karena di daerah ini melewati tempat pembuangan sampah para penduduk sekitar yang membuang sampahnya langsung ke badan sungai,

- Beban buangan di segmen ini sebesar $15,5 \mathrm{mg} / \mathrm{l}$ maka dapat diketahui beban buangan tiap harinya yaitu sebesar 1,65 ton/hari.

\section{Segmen 5,37-7,37 km}

- DO di bagian hulu 0,52 mg/l dan di bagian hilir 7,9 mg/l. Dari hasil perhitungan DO kita bisa melihat ada kenaikan nilai oksigen terlarut, hal ini terjadi karena terjadi hujan pada saat penelitian dan mengakibatkan air sungai menjadi bertambah sehingga terjadi pengenceran didalam badan sungai dan menjadikan oksigen terlarut di sungai ini menjadi bertambah.

- BOD dibagian hulu 6,26 mg/l dan dibagian hilir $7 \mathrm{mg} / \mathrm{l}$. dari hasil perhitungan BOD kita bisa melihat adanya kenaikan nilai BOD, hal ini disebabkan karena adanya masukan beban pencemar di titik $6 \mathrm{~km}$ yaitu sebesar $205 \mathrm{mg} / \mathrm{l}$, selain itu kemungkinan lonjakan konsentrasi di akhir segmen terjadi karena di daerah ini melewati tempat pembuangan sampah para penduduk sekitar yang membuang sampahnya langsung ke badan sungai.

- Beban buangan di segmen ini sebesar 205 $\mathrm{mg} / \mathrm{l}$ maka dapat diketahui beban buangan tiap harinya yaitu sebesar 0,53 ton/hari.

Segmen $7,37 \mathrm{~km}-14,5 \mathrm{~km}$

- DO di bagian hulu 0,93 mg/l dan di bagian hilir 7,3 mg/l, Dari hasil perhitungan DO kita bisa melihat ada kenaikan nilai oksigen terlarut, hal ini terjadi karena terjadi hujan pada saat penelitian dan mengakibatkan air sungai menjadi bertambah sehingga terjadi pengenceran didalam badan sungai dan menjadikan oksigen terlarut di sungai ini menjadi bertambah.

- BOD dibagian hulu 1,46 mg/l dan dibagian hilir 7,5 mg/l. dari hasil perhitungan BOD kita bisa melihat adanya kenaikan nilai BOD, hal ini dipengaruhi jumlah penduduk antara hulu sungai dengan hilir sungai. Semakin banyak jumlah penduduk maka buangan yang masuk ke sungai juga akan lebih banyak. hal ini disebabkan karena adanya masukan beban pencemar di titik 10 $\mathrm{km}$ yaitu sebesar $1466 \mathrm{mg} / \mathrm{l}$, selain itu kemungkinan lonjakan konsentrasi di akhir segmen terjadi karena di daerah ini melewati tempat pembuangan sampah para penduduk sekitar yang membuang sampahnya langsung ke badan sungai, juga terdapat pipa air buangan yang berasal dari PDAM.

- Beban buangan di segmen ini sebesar 1466 $\mathrm{mg} / \mathrm{l}$ maka dapat diketahui beban buangan tiap harinya yaitu sebesar 8,75 tons/hari.

\section{Analisis Terhadap Limbah}

Karakteristik buangan di sungai Citepus tergantung kepada proses industri maupun domestik dan pemanfaatan air pada sungai atau badan air penerima, salah satu parameter yang harus diolah secara umum diantaranya organik terlarut, organik tersuspensi, warna dan kekeruhan dan materi Nonbiodegradable.

\section{Analisa}

Beban buangan yang paling banyak terdapat pada segmen 4 (Segmen 7,37 km - 14,5 km), sehingga perlu adanya pengolahan yang paling penting di segmen ini, karena di segmen ini jumlah penduduknya lebih banyak, terdapat pipa PDAM yang langsung masuk ke badan sungai tanpa adanya pengolahan terlebih dahulu, juga kondisi penduduk yang kumuh. 


\section{Kesimpulan}

Menentukan tingkat pencemaran air sungai akibat limbah/bahan organic yang umum dilakukan hanya berdasarkan parameter kimia fisika yang merupakan indikator sesaat dan penggunaan parameter BOD dan DO dapat melengkapi penentuan tingkat pencemaran karena merupakan indikator pencemaran yang permanen.

Dari hasil perhitungan diperoleh bagian hulu sungai kadar BOD-nya antara 6,8 - 7,2 mg/l dan kadar DO $8,4 \mathrm{mg} / \mathrm{l}$. dan dibagian hilir sungai kadar BOD-nya antara 7,0 - 7,5 mg/l dan kadar DO $0,5-0,9 \mathrm{mg} / \mathrm{l}$. Berdasarkan hasil diatas maka kondisi sungai dibadian hulu kadar BOD di daerah ini telah melebihi ambang batas (tercemar), tetapi nilai DO sesuai dengan ambang batas, begitu juga dengan bagian hilir sungai nilai BOD telah melewati ambang batas (tercemar) dan kadar DO dibawah ambang batas, menurut SK Gubernur Jawa Barat N0.39 Tahun 2000 yaitu nilai BOD sebesar $6 \mathrm{mg} / \mathrm{l}$ dan DO sebesar $>3 \mathrm{mg} / \mathrm{l}$.
Beban buangan yang masuk ke sungai Citepus berkisar antara 0,53 ton/hari - 8,75 ton/hari. Beban buangan yang paling tinggi yaitu di bagian hilir sungai, hal ini disebabkan oleh konsentrasi beban buangan yang masuk lebih besar dibandingkan dengan dibagian sungai.

\section{Daftar Pustaka}

Pangestu, R., Riani, E., \& Effendi, H. (2017). Estimasi Beban Pencemaran Point Source dan Limbah Domestik di Sungai Kalibaru Timur Provinsi DKI Jakarta, Indonesia. Jurnal Pengelolaan Sumberdaya Alam dan Lingkungan, Vol. 7 No. 3: 219-226.

Yustiani, Y. M., Mulyatna, L., \& Pranata, F. (2013). The Deoxygenation Rate Determination Based on Physical Condition of River Body, Case Study of Citepus River. Padjadjaran International Physics Symposium 2013 (pp. 281-284). Bandung: AIP Conf. Proc 1554. 